\title{
The Benefit of Ice Cream to Reduce Emesis Gravidarum of Pregnant Woman
}

\author{
Kiswati* \\ *Department of Midwifery, Health Polytechnic of Malang, Republic of Indonesia
}

\begin{abstract}
Emesis Gravidarum is one of major complications which most often occur during pregnancy. Emesis Gravidarum normally arises approximately 60-80\% of Primigravida and 40-60\% of Multigravida and around 90\% of pregnant women happen to suffer from this particular state of health during pregnancy. Excessive Emesis might cause dehydration and severe malnutrition which will eventually impact on infant's growth and development. The research was aimed at identifying the effectiveness of ice cream in decreasing the level of vomitinging frequency of pregnant women suffering from Emesis Gravidarum. The research design deployed Quasi Experiment with pretest-postest design approach. The research samples were drawn from 57 pregnant women indicated to suffer from Emesis Gravidarum. The research result indicated that the vomitinging frequency of pregnant women with Emesis Gravidarum prior to ice cream consumption was 2 times per day of vomiting of 22.8\%, 3 times per day of vomiting of 43.9\%, 4 times per day of vomiting of 29.8\%, vomiting of more than 4 times per day of $3.5 \%$ and after ice cream consumption of no vomiting of 29.8\%, 1 time per day of vomiting of 28.1\%, 2 times per day of vomiting of 33.3\%, 3 times per day of vomiting of 7.0\%, and respondents with over 4 times per day of vomiting of $1.8 \%$. The research implemented the Analysis of Wilcoxon Match Pairs Test obtained $Z$ count of (-6.869) and $p$ 0.000, which means significant decrease of vomiting frequency of pregnant women was revealed after ice cream consumption on day 5. In other words, Ice Cream consumption during pregnancy will benefit to reduce the risk of Emisis Gravidarum.
\end{abstract}

Keywords: Ice cream, Emesis Gravidarum.

\section{Introduction}

Pregnancy is such an important phase of most women's life in which in some cases, pregnancy which has gone to term with no major risk is most women' expectations. However, risks of pregnancy are dynamic circumstances in which at the first stage, this condition might progress normally, yet it eventually ends up becoming a state with high risk. Thus, antenatal care service becomes one of ways to improve the health of pregnant women with periodical check up for the infant and the prospective mother. During the check up attempts to correct perceived deviations with the aim that pregnant women can get through their pregnancy, delivery and bleeding after delivery well.

In general, pregnancy can be divided into 3 phases such as the first 3 months (Trimester I) with pregnancy age of 28-40 weeks. During the pregnancy, woman's body shows noticeable change due to the increase of estrogen, progesterone and HCG which might cause nausea and vomiting (Prawiroharjo, 2009). In this particular condition, Emesis of pregnant woman remains high. Denise (2004:03) suggested that around 90\% of women suffered from nausea and vomiting during the pregnancy (NVP). Of Sixty five (65) pregnant women at the Public Health Center of Patrang sub-district, $45(69,23 \%)$ of them suffered from nausea and vomiting during the pregnancy(NVP) in 2015.

The causes of nausea and vomiting among pregnant women are multifarious. One of those particular causes is due to the change of hormone in the body, psychological problems, and lifestyle of the prospective mother. Eating disorder prior to and at the first weeks of the pregnancy, lack of rest and stressed can even enable nauseaandvomitingto be even worse. With sufficient rest and nutritious food consumptionthe possibility nausea appearancewill likely be significantly reduced (Denise, 2004:03).

In practice, pregnant women are suggested to independently consume easily accessed food and beverages. Lindsay (1997:508) suggested that fresh fruit and delicious food is normally acceptable. Dairy drinks before rest are also strongly recommended. Denise, (2004:90) stated that food dominantly consisting of protein will reduce nausea and disfunction during stomach emptiness. Therefore, to fulfill the need of nutrition for pregnant women with Emesis is to provide food with adequate nutrition which will not cause nausea and vomiting. Ice cream can represent milk in reducing Emesis and meet the needs of nutrition of pregnant women.

Ice Cream is a delicious beverage which has ability to reduce nausea and vomiting of pregnant women of first trimester. Due to its great deliciousness, women are not threatened to suffer from nausea and vomiting during ice cream consumption. Pregnant women with Emesis normally find it difficult to swallow a wide range of food that gastric acid increase will obviously occur and enables nausea and vomiting to appear so that nutritional balance is impared. Delicious and sweet ice cream provision will also solve nausea during the 
pregnancy. Cold and fresh sensation happens in the throat will cause vasoconstriction which will impede the production of gastric acid. Thus, ice cream consumption especially in the first period of pregnancy is not forbidden. However, pregnant women still have to consider the portion of the ice cream to consume. Pregnant women would rather avoid consuming cold and sweet beverages such as cold and sweet siroup as it contains too much glucose. Siroup does not contain milk, fat and protein as it exist in ice cream. Hence, replacing siroup with ice cream to consume during the pregnancy is strongly recommended.

\section{General Objective}

Identification of the effectiveness of ice cream in reducing the Emesis Gravidarum in pregnant women.

\section{Special Objectives}

1. To identify symptoms of Emesis Gravidarum of a pregnant woman prior to ice cream consumption.

2. To identify symptoms of Emesis Gravidarum of a pregnant woman after ice cream consumption

3. To anlyse the effectiveness of Emesis Gravidarum decrease for a pregnant woman after ice cream consumption.

\section{Design}

\section{Research Method}

The design of the research was determined through the implementation of Experimental Quasi, with the use of One Group of pre test-post test design. The characteristic of the research with One Group pre test-post test design is the identification of cause and effect correlation by involving one group of subjects in which first data collection was previously conducted (pre test) then after treatment, another measurement was carried out to identify the effect of the treatment (post test) Sibagariang (2010). The design of the research is illustrated in the following image of (1):

$$
\text { O1 ----------------------- X ------------------------O2 }
$$

Note:

O1 : Observation of vomiting frequency of pregnant women prior to ice cream provision

$\mathrm{X}$ : Treatment of "ice cream provision"1 cup a day, for 5 days.

$\mathrm{O} 2$ : Observation of vomiting frequency of pregnant women after ice cream provision

\section{Picture (1) : Diagram Research Design}

\section{Population and Research Samples}

Pregnant women at the area of Community Health Center of Patrang subdistrict of Jember regency of East Java Province of the Republic of Indonesiawere actively involved as research populations. Whereas, the samples of the research were taken from 57 pregnant women in the first 3 months (First Trimester) suffering from emesis gravidarum. The criteria of the samples were described as follows; pregnant women of first trimester who suffered from Emesis Gravidarum, yet with no gastric disorder and were willing to be respondents. Samples collection was carried out through simple random sampling technic.

\section{Research Variables}

1. Independent variables are about ice cream provision (X) which means the provision of dairy food with sugar and with rather solid but soft textures containing energy of 3 times more powerful than milk.

2. Dependent variables are about nausea and vomiting (Emesis Gravidarum) appearance prior to ice cream administration (Y1) and Emesis Gravidarum appearance after ice cream administration (Y2).Vomiting was meant as the forceful expulsion of stomach contents via the mouth.

\section{Research Hypothesis}

Ha: there is an impact of ice cream adminisration towards nausea and vomiting decrease (Emisis Gravidarum) of pregnant women in first trimester.

\section{Data Collection Procedure}

The research deployed two sorts of sources of data such as the secondary data which was taken from medical records and collected from the community health center of Patrang sub-district to obtain the data of pregnant women who suffered from Emesis, and the primary data which was collected from questionnaires to identify the level of Emesis of pregnant women and the observation of ice cream provision for the pregnant women. Steps of data collection were described as what follows:

1. Approach implemented towards respondents to obtain letters of respondents' availability. When both agents agreed, respondents were requested to put the signatures on imformed consent. 
2. Questionnaire distribution to respondents to collect data on the level of Emesis Gravidarum of each respondents prior to intervention.

3. Ice cream provision to all respondents .

4. The researcher will conduct an observation on the level of Emesis Gravidarum of each respondent after the intervention on the third day and the fifth day after ice cream provision.

\section{Data Analysis}

To test the comparative hypothesis of two samples in pairs with ordinaldata scale Wilcoxon Mach Pair Test was taken. Comparative hypothesis test used SPSS Program 20 for windows.

\section{The Research Code of Ethic}

1. The research was recommended through the appearance of "ethical clarence"obtained from The Ethic Committee of Politechnic of Health The Ministery of Health in Malang.

3 The research has been officially permitted by the Bureau of People's Unity and Protection of Jember Regency and the Department of Health of Jember regency.

4 Informed consents have been distributed to all respondents

5 All respondets' replies are treated with complete confidentiality

\section{Research Results}

\section{Result}

Tabel (1) Respondents' Characteristic Distribution

\begin{tabular}{|c|c|c|}
\hline Age & $\mathbf{x}$ & $\%$ \\
\hline$<20$ & 4 & 7 \\
\hline $20-25$ & 37 & 64.9 \\
\hline $26-30$ & 14 & 24.6 \\
\hline$>30$ & 2 & 3.5 \\
\hline \multicolumn{3}{|l|}{ Education } \\
\hline Elementary & 4 & 7 \\
\hline Junior High & 13 & 22.8 \\
\hline Senior High & 36 & 63.2 \\
\hline Higher Education & 4 & 7 \\
\hline \multicolumn{3}{|l|}{ Occupation } \\
\hline Civicl Servant & 3 & 5.3 \\
\hline Farmer & 7 & 12.3 \\
\hline Enterpreneur & 8 & 14 \\
\hline Housewife & 39 & 68.4 \\
\hline \multicolumn{3}{|l|}{ Gestational Age } \\
\hline 4 weeks & 12 & \\
\hline 8 weeks & 18 & $\begin{array}{c}21 \\
316\end{array}$ \\
\hline 12 weeks & 27 & $\begin{array}{l}31.6 \\
47.4\end{array}$ \\
\hline 16 weeks & 0 & $\begin{array}{c}41.4 \\
0\end{array}$ \\
\hline \multicolumn{3}{|l|}{ Gravida } \\
\hline Gravida 1 & 32 & 56.1 \\
\hline Gravida 2 & 20 & 35.1 \\
\hline Gravida 3 & 5 & 8.8 \\
\hline Gravida 4 & 0 & 0 \\
\hline Total & 527 & 100 \\
\hline
\end{tabular}

Table 1 ilustrated that most respondents aged $20-25$ years old (64.9\%), nearly all respondents' last education was senior high school $(63.2 \%)$, respondents' occupation was mostly housewives $(68.4 \%)$, the majority of respondents' gestation aged 12 weeks (47.4\%) and as many as 32 people (56.1\%) were at Gravida 1 (first pregnancy).

Tabel (2) Frequency Distribution of Vomiting Prior to and After the Ice Cream Administration

\begin{tabular}{|c|c|c|c|c|c|}
\hline \multicolumn{2}{|c|}{ Vomitinging Frequency per Day } & \multicolumn{2}{|c|}{ Prior to } & \multicolumn{2}{c|}{ After } \\
\cline { 2 - 6 } \multicolumn{2}{|c|}{} & $\mathbf{f}$ & $\mathbf{\%}$ & & \\
1 & 0 time & $\mathbf{0}$ & 0 & 19 & 33.33 \\
2 & 1 time & $\mathbf{0}$ & 0 & 16 & 28.1 \\
3 & 2 times & $\mathbf{1 3}$ & 22.8 & 17 & 29.8 \\
4 & 3 times & $\mathbf{2 5}$ & 43.9 & 4 & 1.0 \\
5 & 4 times & $\mathbf{1 7}$ & 29.8 & 1 & 0 \\
6 & $>4 x$ times & $\mathbf{2}$ & 3.5 & 0 & 100 \\
\hline
\end{tabular}


Table (2) informed that prior to ice cream administration, respondents experienced vomiting more than three times (3x) a day and most of whom encountered vomiting three times (3x) a day (43.9\%), while after the ice cream administration, the majority of respondents did not experience much vomiting (33.3\%).

Table (3) the Wilcoxon Test Results on the Vomiting Frequency Prior to and After the Ice Cream Administration

\begin{tabular}{|l|r|}
\hline Vomitinging Frequency on day 1 & Post - Pre \\
Z & $-5,038^{\mathrm{b}}$ \\
Asymp. Sig. (2-tailed) &, 000 \\
\hline Vomitinging Frequency on day 2 & $-6,833^{\mathrm{b}}$ \\
\hline Z &, 000 \\
\hline Asymp. Sig. (2-tailed) & \\
\hline Vomitinging Frequency on day $\mathbf{3}$ & $-6,724^{\mathrm{b}}$ \\
|Z &, 000 \\
\hline Asymp. Sig. (2-tailed) & $-6,900^{\mathrm{b}}$ \\
\hline Vomitinging Frequency on day $\mathbf{4}$ &, 000 \\
\hline Z & \\
\hline Asymp. Sig. (2-tailed) & $-6,869^{\mathrm{b}}$ \\
\hline Vomitinging Frequency on day $\mathbf{5}$ &, 000 \\
\hline Z & \\
\hline Asymp. Sig. (2-tailed) & \\
\hline
\end{tabular}

As shown in Table (3) on day 5 after the ice cream administration, the analysis obtained value of $\mathrm{Z}$ count (6869)> Z and p-value 0.000, as a result the Null Hypothesis is rejected, which means there is a significant reduction of vomiting frequency in the first trimester pregnant women after day 5 of ice cream administration.

\section{Discussion}

\section{The Frequency of Emesis Gravidarum in Pregnant Women prior to the Ice Cream Aministration}

Of the 57 respondents, those who experienced vomiting twice (2x) a day were as much as $22.8 \%$, three times (3x) a day as much as $43.9 \%$, four times (4x) a day as much as $29.8 \%$, and more than four times (4x) a day as much as $3.5 \%$. The average frequency of nausea and vomiting during pregnancy (NVP) was as many as three times $(3 \mathrm{x})$ a day.

Pregnant women experiencing emesis gravidarum has a great potential to suffer dehydration and other complications harmful for the mother and the fetus. Therefore handling emesis gravidarum as early and accurately as posible is of importance. According Mansjoer (2001) emesis gravidarum are the most common disorder encountered in the first trimester, around $60-80 \%$ in primigravida and $40-60 \%$ in multigravida. This is in accordance with the conditions of pregnant women in Community of Health Center of Patrang Subdistrict consisting of as much as $56.1 \%$ primigravida, and $43.9 \%$ multigravida. Emesis gravidarum are usually triggered by a stimulating scent, the cold weather, sudden wake-up, and food trigerring nausea. Emeris gravidum in pregnant women is usually preceded by nausea, while vomiting is associated with the forceful expulsion of stomach contents via the mouth. The commonly found symptoms of NVP are nausea and vomiting 1-2 times a day or 3-4 times a day, decreased appetite, fatigue, and psychological alterations.

Emesis gravidarum occur due to certain clinical reasons, but some studies revealed that the exact causes of NVP are multifarious. Changes in the endocrine system are known to cause nausea and vomiting during pregnancy. High levels of HCG (Human Chorionic Gonadotrophin), oestrogen and progesterone lead to physiological changes in the gastrointestinal tract, due to the action of the progesterone hormone which relaxes the cardiac sphincter (located between the esophagus and stomach) causes gastric pain and decreases peristaltic intestinal resulting in constipation. As a result, digestion becomes less efficient, and excessive acid in stomach causes nausea and vomiting (Denise, 2004: 05-11). In addition to bad eating habits, unhealthy lifestyle and stress also affect the onset of NVP.

The constant nausea and frequent vomiting in pregnant women are induced by either inadequate intake of nutrients or high protein foods but low in vitamin B6 and carbs which aggravate the psychological burden of women experiencing emesis gravidarum. In addition to nutritional factors, excessive activity and lack of rest can also increase the vomiting frequency itself, especially for housewives with routine household works. Mothers's being reluctant of consuming anti-emetics or emetic milk is also attributed to the high vomiting frequency. Wheras for those with less vomiting frequency regardless of the nausea and vomiting, they have high desire to meet their nutritional needs as well as proper treatment of emesis gravidarum such as taking vitamins or emetic 
milk consumption to help reduce the frequency of emesis gravidarum. The initial management to pregnant women experiencing emetics is usually conducted through counseling on the importance of nutrition for pregnancy by providing alternative food containing adequate nutritional support and safe for consumption. If the smell of hot food triggers nausea, cold food should be prepared. Dairy product like as ice cream are perfectly recommended for women who are sensitive to smell.

\section{The Frequency of Emesis Gravidarum in Pregnant Women After the Ice Cream Administration}

After the $5^{\text {th }}$ day of consuming ice cream, of the 57 respondents, those who did not experience vomiting as much as $33.3 \%$, vomiting once (1x) a day as much as $28.1 \%$, vomiting twice $(2 \mathrm{x})$ a day as much as $29.8 \%$, vomiting three times $(3 \mathrm{x})$ a day as much as $7.0 \%$, and respondents who experienced vomiting four times $(4 \mathrm{x})$ a day as much as $1.8 \%$. The Table showed that there was a decrease of NVP after administration of ice cream.

The strong desire and emotional support from all parties will help pregnant women cope with pregnancy problem and finish it well. Providing supportive counceling by way of appropriate approach will yield significant benefits. In practice, women should be encouraged to try everything on their own and whatever they think they can consume. Fresh fruit and an appetizing meal are generally recommended. Consuming milk before taking a rest is highly recommended as well, although milk is usually the last thing desired by pregnant women suffering nausea (Dewi, 2011), Protein-predominant meal has a positive effect to reduce nausea and dysfunction in empty gastric (Denise, 2004: 05-11). Therefore, one way to meet the nutritional needs of pregnant women with emesis is to provide foods that do not cause nausea and vomiting and contains good and sufficient nutrition. Ice cream is an alternative substitute for milk that can be worth a try to reduce emesis and at the same time be able to meet the nutritional needs of pregnant women. Milk as the basic ingredient of ice cream contains more than 100,000 types of molecules. In addition to water and fat, these molecules include proteins, carbohydrates, minerals, enzymes, gases, and vitamins A, C and D, B 12. Milk also contains several bioactive components such as protein, lactose, fatty acids, minerals, calcium, alfalaktalbumin, Betalaktoglobulin, imunogobulin, lactoferrin, and glikomakropeptida. One of the substances of milk from the group of carbohydrates found in ice cream is lactose which is easily absorbable by the body nd converted to energy. Whereas the function of fatty acid and linoleic acid in ice cream is to increase the activity of antipatogenic, antibacterial, and antiviral. Calcium content in ice cream is useful for maintaining bone density, prevention of osteoporosis, cancer, and hypertension (Astawan, 2009).

Providing dairy products including ice cream also has a high contribution to the health of the body and is safe for consumption by pregnant women with a reasonable dose, ie 2-3 cups per week. In pregnant women with emesis it is usually difficult for them to swallow certain types of food, resulting in an increase in stomach acid, which causes nausea and vomiting. It can trigger the impared balance of maternal nutrition. Giving a cold delicious ice cream also can help overcome nausea during pregnancy. Cold sensation in the throat makes the body fresh and causes vasoconstriction that also inhibits gastric acid expenditures.

Emesis Gravidarum can usually be managed by avoiding trigerring nausea smells, taking small amounts of liquid and food throughout the day rather than eating fewer but larger meals, avoiding greasy, spicy, and hard food, slow getting-up, avoiding immediate toothbrushing after eating, drinking herbal tea or ginger, providing vitamin B6 supplementation, avoiding beverages containing caffeine such as coffee and softdrink, as well as adequate rest.

\section{A Decrease in the Frequency of Emesis Gravidarum in Pregnant Women After the Ice Cream Administration}

This study found a very significant declined in the frequency of emesis gravidarum after the $5^{\text {th }}$ day administration of ice cream. Coping with the symptoms of emesis gravidarum as early and independently as possible is very important, since late treatment can interfere the pregnancy and cause a variety of harmful complications. Pregnant women with symptoms of hyperemesis gravidarum have great potential of suffering from dehydration, lack of carbohydrates and fats in the body and can also generate small tears in the mucous membranes of the esophagus and the gastric or even Mallary Weiss syndrome due to gastrointestinal bleeding (Yuliani, 2009). In this regard Denise (2004) states that pregnant women should be encouraged to try everything on their own and whatever they probably feel able to eat or drink when experiencing symptoms of emesis. This indicates how important it is to maintain nutrition in a state of emesis for suppressing the production of gastric acid that can aggravate emesis.

This study found that some respondents still experienced vomiting after the intervention but with less frequency compared to prior to the ice cream administration. They who were still comitting vomiting after the intervention were those of the respondents with higher vomiting frequency than other respondents.

The results of this study are consistent with the theory stated by Denise (2004) that High levels of HCG (Human chorionic gonadotrophin) can lead to physiological changes in the gastrointestinal tract. It is due to the reaction of the hormone progesterone which relaxes the cardiac sphincter (located between the esophagus and 
gastric) causing gastric pain and decreased peristaltic intestinal as the contributory factor to constipation. As a result digestion becomes less efficient and excessive gastric acid causes nausea and vomiting (Denise, 2004: 0511). Dietary and lifestyle also contributes to the coourence of emesis gravidarum. Some studies show that mothers who consume protein-predoimant meals but lack of vitamin B6 and carbohydrates are more likely to suffer from nausea and vomiting while the lack of rest and psyhological burden can exacerbate nausea (Suririnah, 2010).

In conclusion, adequate nutrition is indeed necessary at the state of emesis gravidarum to reduce the production of gastric acid as the cause of vomiting and its high frequency. Finding the right management is important for pregnant women suffering from emesis gravidarum as they tend to avoid some foods and beverages with pungent odor and so on. That is why proiding food with adequate nutrition is the key to suppress the frequency of vomiting.

\section{Conclusion}

\section{Conclusions and Recommendations}

The conclusion resulted from this study is a significant reduction in the frequency of vomiting in the first trimester pregnant women who experience emesis gravidarum after the $5^{\text {th }}$ day of administration of ice cream. Thus consuming ice cream is effective in reducing nausea and vomiting in pregnant women.

\section{Recommendation}

Health workers can reccommend the adminsitration of mouthwatering ice cream of various flavors to pregnant women with emesis gravidarum symptoms to meet their nutritional needs and their fetus. Pregnant women with emesis gravidarum symptoms are suggested to consume ice cream to prevent the exacerbation of its symptoms because the content meets the prerequisited nutrients of healthy pregnancy.

\section{References}

[1]. Astawan, (2009), Makanan Sehat Bagi Ibu Hamil, www//http:Infogizi.com

[2]. Astawan, ,(2009), Kandungan Gizi Es Krim, www//http:Infogizi.com

[3]. Denise, (2004), Mual dan Muntah Kehamilan. Jakarta, Buku Kedokteran EGC.

[4]. Dewi, (2011), Asuhan Kehamilan Untuk Kebidanan. Jakarta, Salemba Medika.

[5]. Mansjoer, A. ( 2009), Kapita Slekta Kedokteran. Jakarta, Aesculapius Media.

[6]. Prawiroharjo, S. (2009), Ilmu Kebidanan. Jakarta, PT Bina pustaka Sarwono Prawirohardjo.

[7]. Sibagariang, (2010), Metodologi Penelitian Untuk Mahasiswa Diploma Kesehatan. Jakarta, Trans Info Medika.

[8]. Suririnah, (2010), Tips Mengatasi Mual Muntah Pada Hamil Muda, www//http:infoibu.com

[9]. Yuliani, (2009), Diktat Kuliah Asuhan Kebidanan 1. Jakarta, Trans Info Medika. 